\title{
THE CHORÁ OF PATMOS (GREECE): ANALYSIS OF ARCHITECTURAL HERITAGE, IDENTIFICATION OF RISKS AND ASSESSMENT OF IMPACTS
}

\author{
L. Dipasquale ${ }^{1, *}$, L. Montoni $^{1}$, A. Manzi ${ }^{1}$, S. Mecca ${ }^{1}$ \\ ${ }^{1}$ Department of Architecture, DAR|MED Lab, University of Florence, Italy - (letizia.dipasquale, saverio.mecca) \\ @unifi.it, (luciamontoni, alessadra.manzi)@gmail.com
}

\author{
Commission II - WG II/8
}

KEY WORDS: Heritage Impact Assessment, Heritage management, Conservation, Mediterranean architecture, Risk management.

\begin{abstract}
The Historic Center (Chorá) of Patmos, located in one of the Dodecanese Islands of Greece, was inscribed in the World Heritage List in 1999. The morphological feature, the housing typologies and the building techniques that characterize the Chorá provide an authentic and astonishing expression of the stylistic and typological models of the vernacular architecture of the Greek islands. This paper presents part of the research carried out on the Chora of Patmos, within the 3D Past project, funded by the European Creative Europe program. The first part illustrates the results of the research concerning the analysis of the material components of the architectural heritage of Patmos: the urban structure, the evolution of the main architectural typologies, the feature of the main building systems. The second part of the paper presents the application of the Heritage Impact Assessment (HIA), a tool for the management of site transformations and in particular for identifying, forecasting and evaluating the impact of potential development on the Outstanding Universal Value (OUV) of the properties. In the case of Patmos the application of HIA can provide an important contribution to manage changes and future transformations in order to preserve the cultural significance of the site and ensure its sustainable development.
\end{abstract}

\section{INTRODUCTION}

Patmos is the northernmost island of the Dodecanese, as well as one of the smallest inhabited islands of this Greek archipelago. The Chora of Patmos is located at the highest point of the island, about $200 \mathrm{~m}$ above the sea (Figure 1). It is one of the best preserved and oldest of the Aegean Chorá (Philippides, 1999). Its origins, going back over 900 years, derives from the development of an agrarian settlement created to support the monastery dedicated to St. John the Baptist, which was founded in 1132. It is characterized by compact, whitewashed volumes, terraces that fit together and adapt to the morphology of the ground. Since 1999 The Historic Centre (Chorá) with the Monastery of Saint John the Theologian and the Cave of the Apocalypse on the Island of Patmos have been added to UNESCO's World Heritage List. The city represents one of the few settlements in Greece that has developed continuously since the 12 th century. It is known as the place where the apostle St. John, during his exile in $95 \mathrm{AD}$, wrote the Gospel and the Apocalypse. Along the road that connects Chora and Skala, the port city of the island, there is the Cave of the Apocalypse where according to tradition the sacred books were written.

To date, the built heritage of Chorá appears to be rather well preserved, both as regards the state of the historic buildings, and the containment of the urban sprawl outside the boundaries of the ancient settlement, which would otherwise have altered its authenticity. Patmos boasts a territory of high landscape value already recognized in the 1970-71 regulations as "historical and landscape monument" first, and subsequently as "historical monument and place of special beauty". The extension of the city of Chorá, on the ridge of the mountain, is particularly appreciable from the surrounding hills and, although new buildings have been identified on the borders, we can consider the boundaries of the settlement almost completely unchanged.
The built heritage of the Chorá is nowadays strongly at risk as it is affected by a phenomenon of abandonment by the inhabitants and is also facing new pressures for transformation with the purpose of encouraging mass tourism. Threats and dangers for the preservation and conservation of the site are therefore identified through an analysis of risk factors.

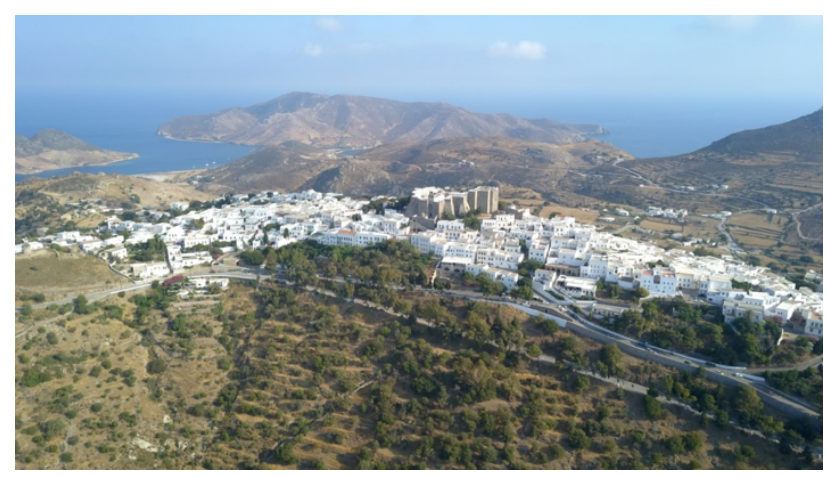

Figure 1. Island of Patmos and view of the Chorá.

\subsection{Methodology of investigation}

The results presented in this paper are part of the research carried out within the project "3dPast - Living \& virtual visiting European World Heritage". 3D Past project is funded by the Creative Europe EU program, and involves the Escola Superior Gallaecia (PT) as coordinator, the Universitat Politècnica de València (ES) and the Università degli Studi di Firenze (IT) as partners. The project is focused on enhancing of both the tangible and the intangible component of the heritage of the European World Heritage sites characterized by the presence of vernacular architecture. The project aims to highlight the importance of

* Corresponding author 
preserving the building authenticity and integrity, disseminate the local knowledge associated with the inhabited vernacular dwelling, sharing with European citizens vernacular architecture quality and its intangible local know-how.

The first part of the research concerned the analysis of the material components of the architectural heritage of the Chorá of Patmos: the urban structure, the evolution of the main architectural typologies and the feature of the main building systems. The analysis was conducted by crossing what little information was available in the literature with the results of the field research, which was based on direct observations and surveys of the buildings, interviews with inhabitants, professionals, local experts and administrators.

The second part of the paper presents the application of the Heritage Impact Assessment (HIA), a tool for the management of site transformations (Pereira Roders, Van Oers, 2012). An approach focused on risk analysis on heritage has been applied to identify possible strategies for the conservation and sustainable development of the Chorá. The Heritage Impact Assessment was therefore used to evaluate a rehabilitation project hypothesized for a ruined area of Chorá. In the future the same tool may be applied to expansion and development projects for identifying, forecasting and evaluating the impact of potential development on the Outstanding Universal Value (OUV) of the properties.

\section{ANALYSIS OF ARCHITECTURAL HERITAGE}

\subsection{Urban structure}

Chorá can be reached via the only driveway that runs along the entire island and a nineteenth-century pedestrian street that connects it with Skala. The city boundary is well defined and there is a clear transition from the urbanized area to the surrounding rural area. The fortified monastery dedicated to St. John the Theologian represents the core of the settlement and the volume that dominates the city (Figure 2). It is placed on the top of a promontory and has the appearance of a castle. It was built in 1088 by the will of the Byzantine emperor Alexios I Komnenos, who had seen in Patmos a possibility of control over the Aegean. Unlike other Orthodox monasteries, mostly isolated, a dense urban structure develops around the monastery of Patmos. The settlement features numerous small churches inserted in the urban fabric, some private chapels and others open to the community, which contain valuable pictorial elements (Olympitis, 1997). To the south-west of the town is the Zoodochos Pege female monastery, another large religious complex, founded in 1605 .

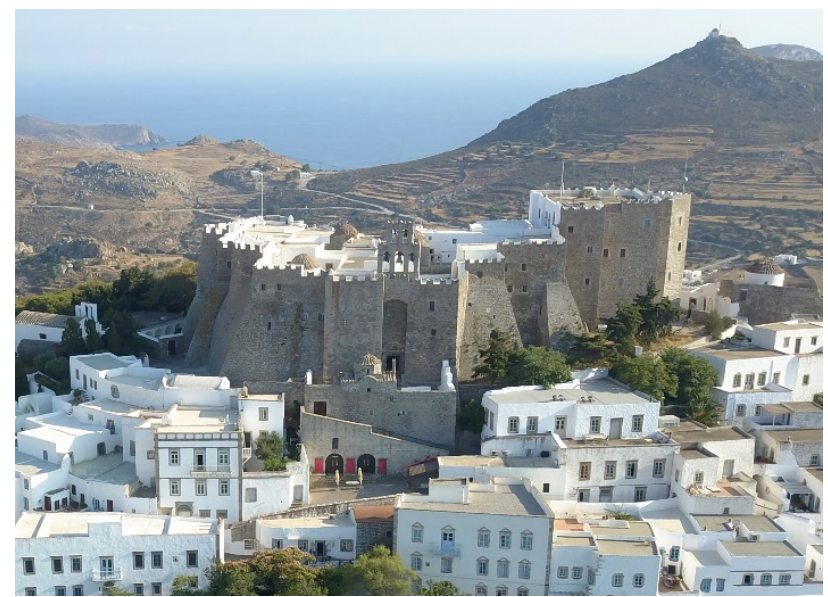

Figure 2. Monastery of Saint John the Theologian.
The urban structure is compact and the streets are narrow and winding, with an irregular pattern without main axes, almost labyrinthine (Figure 3). The irregular laneways sometimes end in a blind alley, revealing themselves to be simple clusters of access to homes. The houses are arranged along the slope, creating a particular play of different volumes and heights. In general, the houses are built on one or two floors, except for the 19th Neoclassical buildings, which can reach three floors. The presence of courtyards and terraces in the front of the house facing the street creates a particular play of full and empty spaces and terraced volumes. The presence of many covered passages, which were formed with the expansion of the second floor of the houses, further characterizes the urban morphology. The green spaces included in the urban area are usually inside private properties.

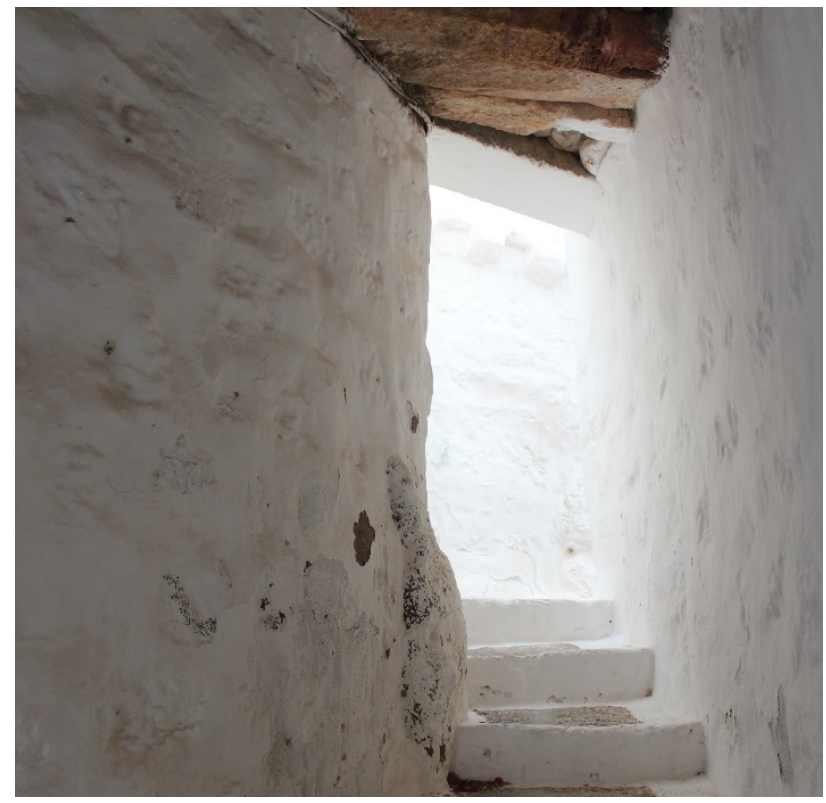

Figure 3. Narrow and covered passages of Chorá.

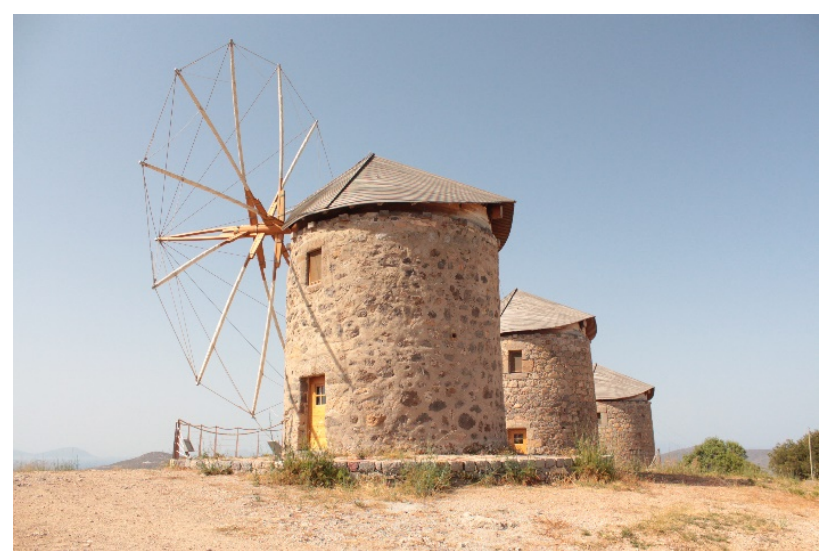

Figure 4. Windmills.

Through the observation of the different building types, it is possible to read the various historical moments of urban expansion (corresponding to migratory flows). There are three main periods that defined the trend of Patmos architecture (Papadimitriou, 1982):

- the first, between 1250 , the year the city was founded, and 1832, when Greece gained independence: it is a period of great development of traditional architecture; 
- the second, between 1832 and 1947, during the Italian occupation, was characterized by degrowth and migration;

- the last, from 1947 to today, is the period characterized by the appearance of mass tourism, economic growth and the increase in construction activity.

The few productive and commercial activities are distributed along the road that from the north access to the city reaches the monastery, and on the main square to the east of the latter. In ancient times there were two important internal axes; the commercial one, to the east of the monastery, corresponding to the current one, and one to the west of the small artisan shops. Windmills have been built since 1588 for grinding cereals and other agricultural products. Located in an area on the edge of the city, they are architectural elements that strongly mark its profile (Figure 4).

\subsection{Functional organization of the house}

The oldest form of residence develops around the walls of the monastery and consists of a single room on one floor, called a monospito (mono + spiti) or ospition. The term ospitium probably derives from the Byzantine hospitium (Filindra, 1975). In its simplest form, the house corresponds to a rectangular volume 2.8-3.5 x 7-8 $\mathrm{m}$ and $3.5 \mathrm{~m}$ high. (Phase 1, Figure 5) The distance of the walls in width depends on the length of the wooden beams, and the ratio between the dimensions always remained about $1: 2: 1$. The building developed according to the morphology of the slope, parallel to the contour lines with the entrance mainly located on the short side. Internally the cell structure is divided into two parts (Figure 6). The first, on the side of the entrance, called spiti, is dedicated to the daily activities of the home such as cooking and handicrafts. The second, on the back of the building and called camari, constitutes the sleeping area. The division between the two rooms is obtained through a partition in stone, wood or fabric, which defines the relationship between the two spaces (1:2), where the sleeping area is the smallest part. A first evolution of the module concerns the insertion of a new space between the street and the building (Phase 2, Figure 5); an entrance courtyard, called avli, with oven and underground cistern. In the case of larger courtyards it's possible to find a sink, a grinder, a fireplace or a rudimentary bathroom. The presence of a courtyard surrounded by high walls, in almost all the houses of Chorá, shows a clear desire for separation between the public and private space (Arikan, 2015).

The subsequent changes relating to the expansion of the house consist in the addition of a second floor or, where possible, in the horizontal extension through the repetition of cells side by side or the insertion of a volume arranged perpendicularly to form an L with the existing building. Single-storey housing is not very common today. In fact, most of the cases studied are relatively more articulated buildings and very often on two floors, the result of integration and transformation processes to meet space requirements. The two-storey house is called anogokatogo and consists in overlay of cells (anoi + katoi). (Phase 3, Figure 5) The two-storey houses of Patmos differ from similar cases in mainland Greece, where the ground floor was generally used as a barn, warehouse or stable, since the ground floor here was part of the house.

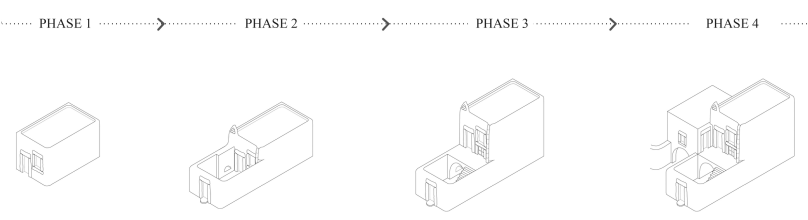

Figure 5. Phases of dwellings' development.
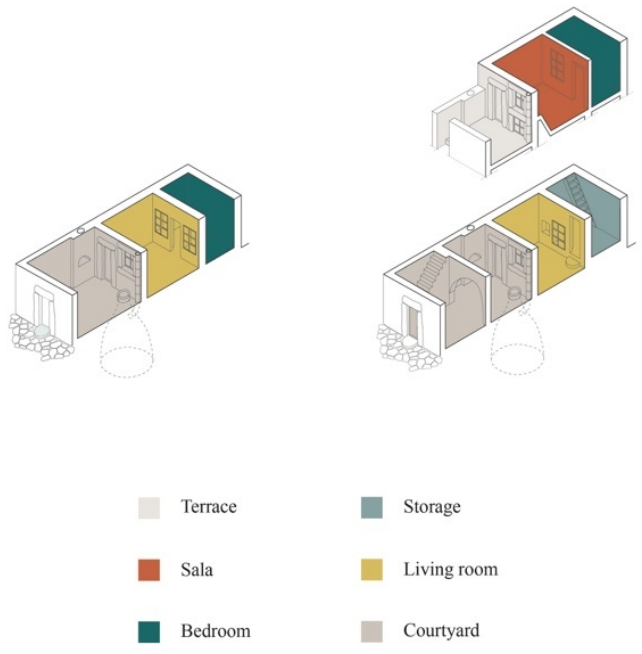

Figure 6. One and two storey house.

The courtyard is divided into an entrance and an external area, covered by the upper terrace, and houses the oven and the cistern. The terrace, called pano avli, is reached by a main external staircase located near the entrance to the courtyard, and by an internal one, called katarrachias, which is located in the sleeping area. The added terrace is supported by an arch on the ground floor, which creates a mediation between the open space of the entrance and the covered one. On the first floor we find a formal space for feasts, called sala or kalospito, usually $4.5 \mathrm{~m}$ wide and $7.5 \mathrm{~m}$ long, considered the most important place in the house and therefore much more refined in the furnishings. It was in fact the showcase of the house for visitors. At the back of the room there is the sleeping area, separated from the previous area with a lighter wooden partition. In the wealthiest residences this wooden structure is very articulated and decorated with carved and painted decorations. This complex alcove takes the Greek name of ambataros. The best preserved example can be found in the Nikolaidis house-museum (Figure 7).

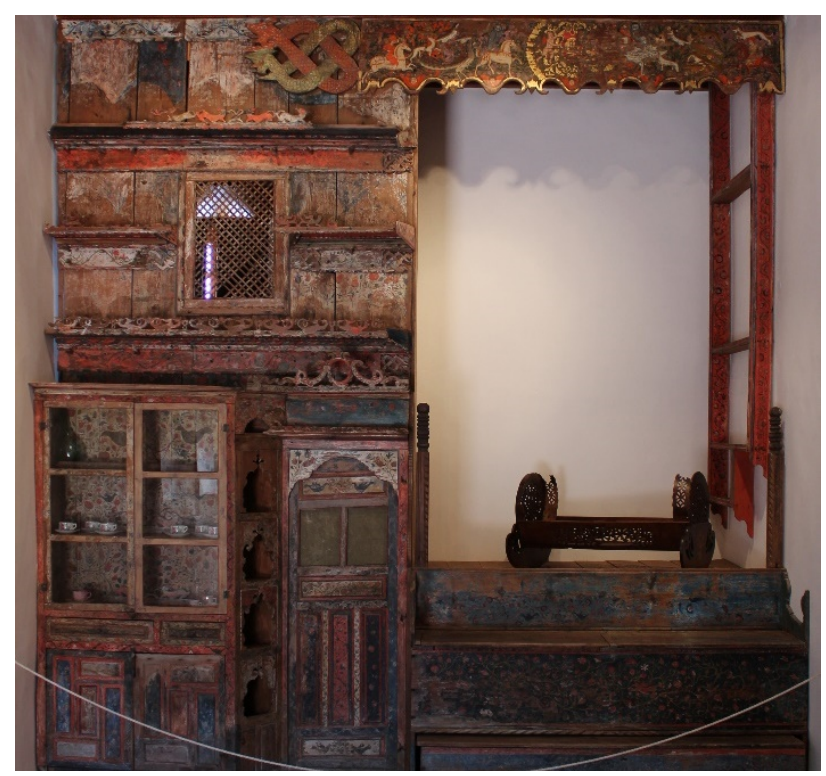

Figure 7. Nikolaidis' house-museum ambataros.

Subsequently a guest room with an independent entrance, called ondas or nondas, is added to the house, which serves both as an observation point to control the street below and as a secret 
passageway connecting with the adjacent property which was on the other side of the street. (Phase 4, Figure 5) In case of attack, the inhabitants had the opportunity to get into a protected area and defend themselves thanks to this system.

In the 16th-17th centuries, agricultural complexes characterized by the desire for independence from the monastery and its social role spread in the area outside the first inhabited nucleus, underlined by the presence of a defensive wall and tools proper for various processes. The structure of the compound was characterized by several two-storey modules with alternate open and closed spaces. The ground floor included courtyards, cisterns, oven, kitchen, storages and grains, while on the upper floor were the sleeping area, the rooms and the terraces. Today these complexes have been incorporated into the urban sprawl and have been fragmented into several housing units (Iakovides, Philippides, 1990).

From 1832 three-storey buildings arose in the northern area of Chorá, replacing the defensive wall towards the port of Skala. These were the large and luxurious homes of wealthy ship owners and merchants who chose this position in order to observe the ships from above and to be able to show off their economic and social position. Maritime and commercial exchange with the outside favoured the spread on the island of new architectural styles, in particular of the neoclassical tradition. These mansions in fact stand out within the settlement for their dimensions. Compared to the traditional typology, there is also a lower flexibility of the internal spaces where the rooms are connected by a corridor or communicate through distribution spaces and each room has a specific use.

\subsection{Main architectural typologies}

Based on the observation of case studies, two main types of buildings have been identified (Figure 8). The first starts from the basic module (simple cell) and develops in a multitude of variants that arise from the horizontal or vertical combination of one or more cells. It is the most widespread and characterizes the vernacular urban structure of Chorá. The second type is more recent and incorporates neoclassical elements.

The first typology is between the 13th and 19th centuries. The variants depend on the way of aggregation of the simple cell and its position in the block that are influenced by the morphology of the site. The main variations can be classified as:

1a. buildings consisting of simple cells with one or two floors and the entrance on the short side;

1b. buildings, with one or two floors, resulting from the overlay of one or more cells, with the entrance on the short side;

1c. buildings with one or two floors, with entrance on the short side and added modules in an irregular way so as to create variations to the scheme and dimensions of the base cell;

1d. buildings with the entrance in the long side of the cell, with one or two floors, simple or complex.

The second typology was born at the end of the 19th century and corresponds to buildings with Neoclassical influence. Despite the break with the previous architectural typology, there are some elements of morphological continuity such as the rounded corners and the frames of the exposed stone openings. The new construction trends were also accompanied by the use of a different stone, with a prevalence of limestone, and imported materials, such as marble and gypsum.

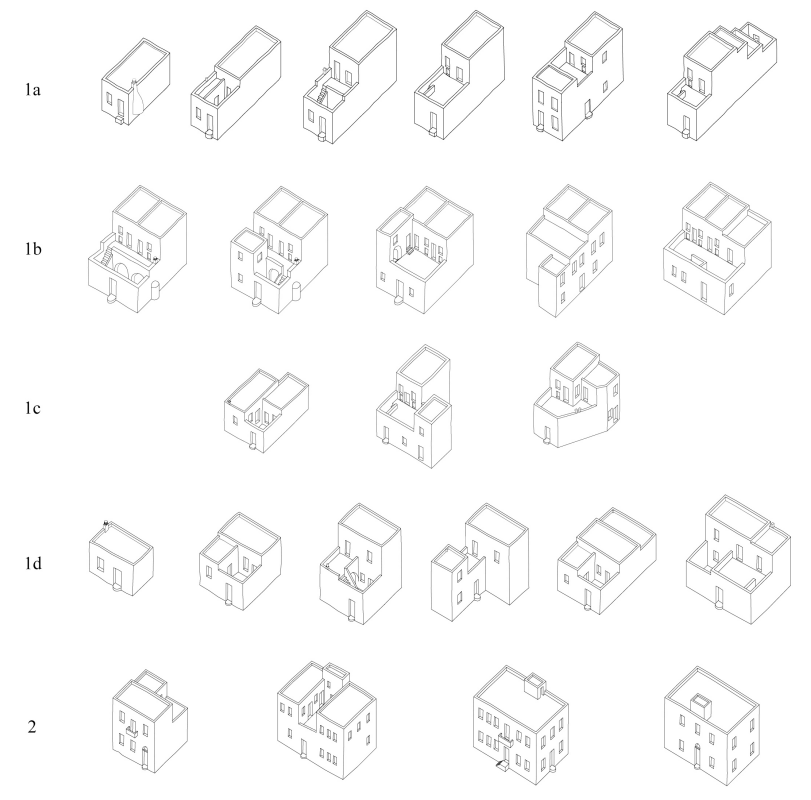

Figure 8. Architectural main typologies and variants.

\subsection{Main building systems}

The buildings are made of stone, the predominant material on the island, which has a rocky nature. In most cases the external walls have a limewash covering. The walls are made with two lithotypes: grey granite rock and ochre-beige limestone. The thickness of the masonry varies between 55 and $65 \mathrm{~cm}$ and, in general, decreases as the height of the building increases. Stones are squared and brought to hammer-dressed or straight cut finish before being laid. Stone elements can be more or less dressed, depending on the importance of the building. They have the approximate dimension of 20x20x40 $\mathrm{cm}$ and they are laid in horizontal courses of equal layers with uniform and staggered joints (Figure 9).
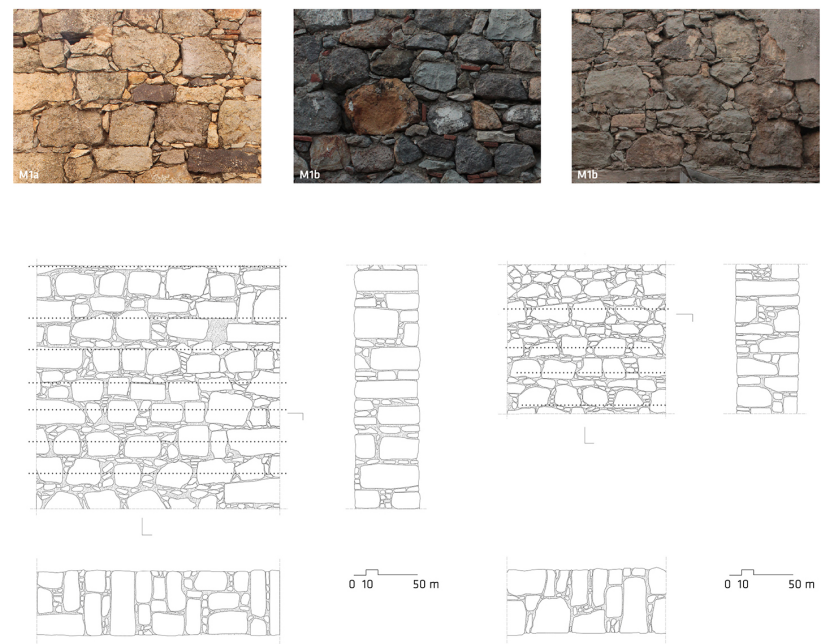

$\sqrt{010 \quad 50 \mathrm{~m}}$

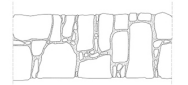

$\sqrt { 0 } \longdiv { 5 0 } \mathrm { m }$

Figure 9. Stone and dry stone masonry.

Smaller stones, stone flakes or bricks are used to fill the uneven gaps remaining among the stones and to improve the uniformity of the wall texture. Through stones, which occupy the entire thickness of the wall, are used to connect the two external faces. The corner of the walls are made with particular attention, using ashlar blocks and very tight mortar joints. At the ground floor, corners are rounded off to facilitate the passage of the carts 
through the narrow streets of the Chorá. Corners and frames of the openings are not the plastered, unlike the rest of the building. The mortar used for the walls is always based on earth and lime, while the finishing plasters are composed of sand and lime, with the possible addition of straw. Terraces and fences are made with dry walls without the use of mortar.

The openings are generally few and located on the main front of the house. The structure is made using the technique of the architrave system which in Greek is called mantomata. In smaller quantities there are also arched openings with a round arch, always made with granite or limestone (Figure 10).
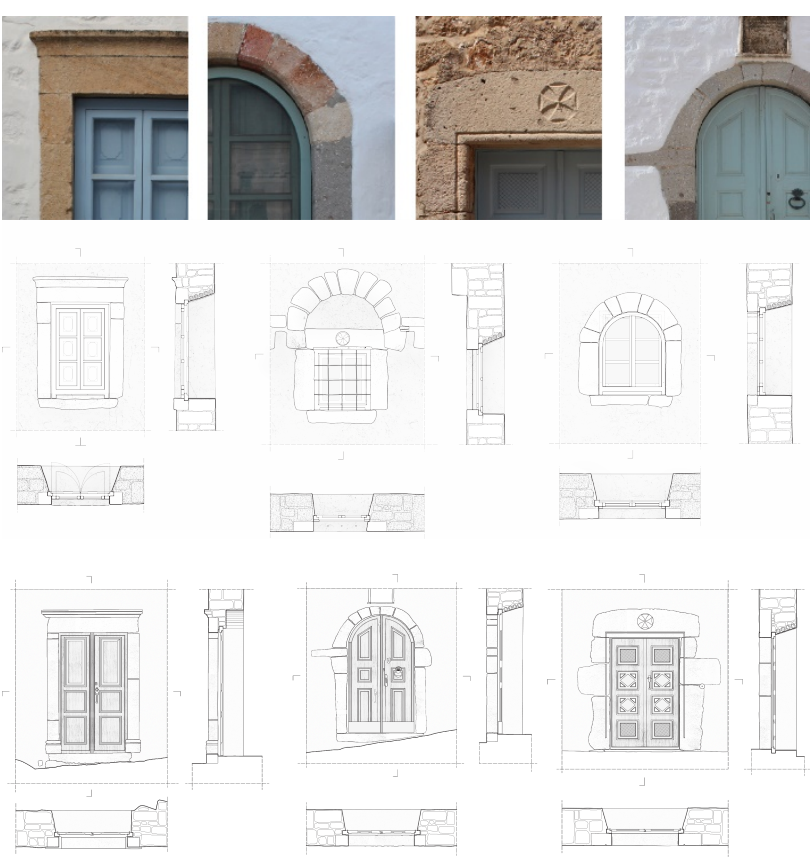

Figure 10. Openings with frame or round arch.
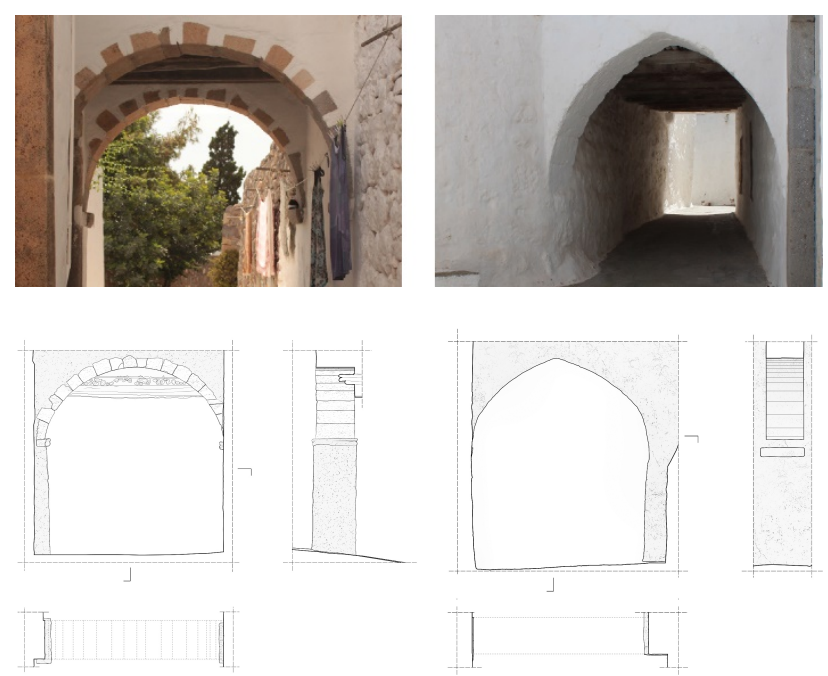

Figure 11. Segmental and pointed arch.

Despite the difficulty of engraving the stone, it is typical to find a cross decoration on the lintel of the doors or the date of construction of the house and the initials of the owner. For the openings of the covered passages 3-3.5 m wide, arches or masonry vaults were used, which in Greek are called voltos or kamariko. Lower arches and pointed arches were introduced to support the terrace inside the two-storey buildings and to support the covering of public passages, so as to allow the construction of a second level above them (Figure 11). The facades sometimes have discontinuities owed to projections of the upper floor; these serve to give greater regularity to the first floor, as the ground floor often followed the uneven boundary lines.

Most of the buildings in Patmos have rooms that develop in length for a maximum of $3.5 \mathrm{~m}$, which is why the most recurrent floor is the one with simple warping where the structure rests directly on the load bearing longitudinal walls (Figure 12). The warping of the joists is parallel to the shorter side of the cell that usually faces the street. Wooden joists have regular-size, usually $7-12 \times 8-15 \mathrm{~cm}$. Sometimes thicker rough trunks, $4-8 \mathrm{~cm}$ in diameter are used.
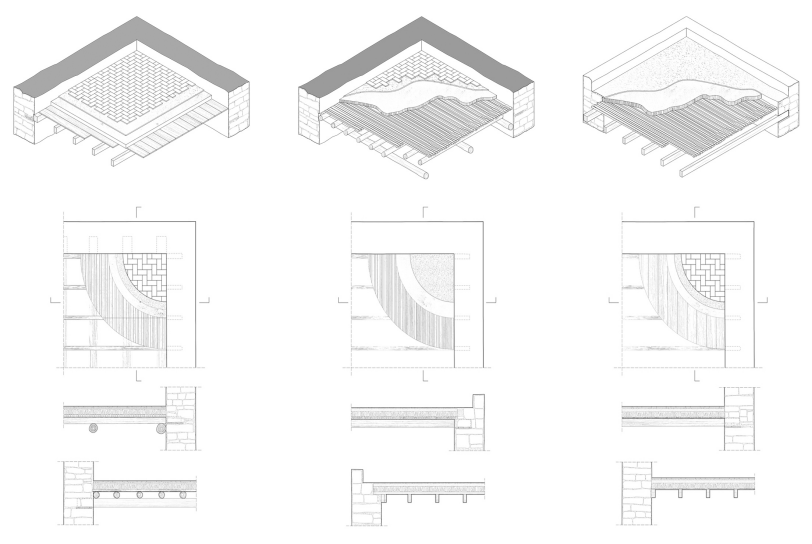

Figure 12. Constructive typologies for floors and roofs.

In the covered passages or in case of bigger spans a main transversal structure, generally consisting of cypress wood trunks of about $10-20 \mathrm{~cm}$ in diameter, is arranged every 50 to $120 \mathrm{~cm}$. The nailing of additional beams to the intrados of the supporting beams is a solution used in constructions subsequent to 1720 . This allowed to temporarily solve the structural problems due to dimensional deficiencies and the age of the floor beams. Above the rafters there are wooden boards, juxtaposed or reed branches that constitute the support layer for the filling screed, $10-15 \mathrm{~cm}$ thick, mainly composed of vegetables with dry bushes and seaweed. Above is a layer of clay-based bedding about 2-4 cm thick, on which the last finishing layer is placed.

The traditionally most widespread roof of Patmos is flat, except for the churches, which usually have barrel-vaulted roofs. The structure of the roofs does not differ from that of the floors and the total thickness reaches a maximum of $35 \mathrm{~cm}$.

The stone paving is used in the entrance courtyard, the typical Patmos ceramic tile is used in the living area on the ground floor and in the terrace on the first floor. In the interior spaces, the floors consists of either ceramic tiles (keramidia) or wooden boards. Ceramic tiles have variable dimensions with a thickness from 3 to $5 \mathrm{~cm}$ and a maximum width and length of 12 and 30 $\mathrm{cm}$, always in a 1:2 ratio. For the external spaces (the terrace and the courtyard) the flooring is arranged according to a design of parallel rows. The problem of possible water infiltration has been solved by arranging a row of inclined tiles at the junction point between the floor and the perimeter wall. The interior spaces floors are enriched with decorations through different 
compositions of the tiles. As for the roofs, the beaten earth, lime and crushed tiles (kourasani), which also constitutes the last finishing layer, must be put in place in order to guarantee the correct outflow of rainwater into the cisterns, with which all the houses are equipped. In the past, the use of a little cohesive clay was the main problem in the collection of water as it broke away with the first rains and filled the tanks. So the inhabitants, at least once a year, had to clean the inside of the tanks from the mud. To solve this problem, tiles were added to the roofs of richer homes.

\section{RISKS AND IMPACTS ON HERITAGE}

\subsection{Identification of main risks on the heritage of Patmos}

In order to prioritize, make choices and identify strategies about how best to use the available resources to safeguard the Outstanding Universal Values and plan the sustainable development of the site, the possible and imminent risks to the cultural property have been identified (Nijkamp, Riganti, 2008). Risk analysis is a process that is normally adopted in the phase of developing a site management plan. Risk-Based Thinking is introduced into the new generation rules on a site's management systems. Risks to heritage sites can be either natural or anthropogenic. They can depend on the inherent vulnerability and geographical environment of the site, or on different human activities, including development and tourism strategies, inappropriate management, lack of maintenance and neglect or political decisions. Risk-Based Thinking is based on the need to identify the risk and opportunity factors in order to reduce the negative effects that could change the processes and management systems with respect to the planned results (Mecca, Masera, 2002).

In this case, the information deriving from interviews with the municipal authorities, direct observation of the site, recommendations and evaluations in the 2014 Periodic Report were processed to identify safety needs and risk factors.

In the Chorá of Patmos a rehabilitation project was hypothesized for the UNESCO area (it was a design proposal developed for a degree thesis). The organizational approach of Risk-Based Thinking has made it possible to recognize the possible risks for the preservation of the identity and the safeguarding of the site, so as to direct strategies towards rehabilitation projects capable of minimizing the greatest risks in terms of severity and probability of occurrence. Three investigation tools were used in the research: the Fault Tree Analysis (FTA), the SWOT analysis and the Consequences/probabilities matrix. From the first analysis carried out through the FTA, the following problems emerged: depopulation; seismic risk; decay of some areas; potential loss of local crafts; potential impact of mass tourism.

The island has a fairly intact architectural and natural heritage and is far removed from mass tourism phenomena that inevitably influences the typical features of the places. The difficulty in reaching it has protected the site from large tourist flows and has developed elite tourism interested in the preservation of traditional characters. However, there was a low presence of permanent residents and therefore a lack of a community able to keep the site active throughout the year. The appeal of Chorá has attracted many foreign tourists who have purchased residences and settled in the island (Theocharopoulou, 2009). If on the one hand this has initiated a series of good actions, such as restorations and renovations works, on the other it has triggered a process of removal of the inhabitants in favor of selling or renting to foreigners resulting in higher house prices. Renovation and recovery of fabrics is also a high-cost option since changes to the assets are subject to regulations to safeguard and preserve the authenticity of the buildings. The tendency for residents to leave their homes could compromise the identity function of its social tissue. It should be stressed, in fact, that it is precisely the combination of cities and citizens that constitutes the identity of a place. Within the settlement there are few services for those who permanently live in that place, but at the same time the centre is inhabited by a small number of people who would not justify an enhancement of these; thus the city of Skala, on the sea, remains the main point of reference and center of attraction. In fact, movements towards the port city have been recorded but, even more strongly, the phenomenon of migration to other parts of Greece.

The settlement is characterized by the majority of densely built residential areas that leave few public spaces for social interaction and no freely accessible green space. This type of organization of the urban structure leads to living the settlement as a place of passage, especially in those parts without commercial activities. The deteriorated state of some areas could be considered a consequence of the high costs and depopulation, since when a space is lived spontaneous maintenance and conservation mechanisms are triggered even in areas with little tourist attendance. Despite the good general state of conservation, there are numerous artefacts in a state of decay or abandonment, mainly in the south-west area, the one most isolated from the activities (Figure 13).

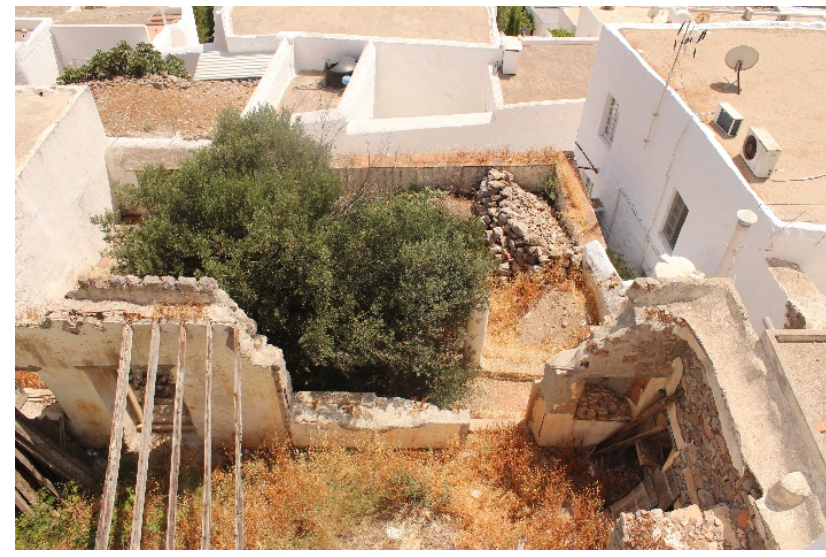

Figure 13. A ruined house inside Chorá.

Some state organizations have shown interest in the recovery of buildings in bad condition such as the Nikolaidis house which, after the damage suffered during the 1956 earthquake, has now been transformed into a museum which houses some cultural events and a permanent exhibition on the history of the island. Patmos is located in an area with a high seismic risk and, despite the traditional techniques that reveal the presence of some antiseismic construction measures, another element of weakness could be the lack of recent consolidation and strengthening of the structures.

Among the potential risks encountered, the loss of local craftsmanship, in particular of ceramic artisans, and the impact of mass tourism were also identified. This first phenomenon is analyzed with a view to progressive detachment from traditional artisan crafts in the new generations and a dynamic market that requires innovation and internalization of the artisan product. The second phenomenon, on the other hand, is to be investigated especially in relation to the experiences of the nearby islands that have undergone a tourist boom upsetting some values maintained up to that moment. Patmos is an island that has a copious flow of 
tourists both for its architectural value and as a pilgrimage destination being one of the seven most important Christian sites. The consequences/probability matrix was used to classify the identified risks: a tool used to evaluate the risks and establish a priority with respect to the management and development plan. With the matrix the value of the risk is obtained as a product between the consequences/damages caused by the risks and the probability that they will occur. To reduce or eliminate risks, measures must be identified that can lead to the mitigation of the severity of the damage (with protective measures) and/or frequency (with preventive measures). The main problems to be faced are the loss of residents in Chora and the possible extension of areas of degradation due to the neglect and carelessness of an absent citizenship.

\subsection{Application of Heritage Impact Assessment}

The Heritage Impact Assessment (HIA) is a methodology, still experimental, created for the identification, forecast and assessment of the impact of new interventions on a World Heritage site. It was introduced by ICOMOS within the Guidance on Heritage Impact Assessments for Cultural World Heritage Properties (2011) and allows to respond to the transformation needs of the sites in a systematic and coherent way. The aim of this tool is to safeguard the values which allowed to include the site in the World Heritage list. The results and conclusions of the HIA are therefore integrated into the planning and decisionmaking process to mitigate the negative effects and improve the positive aspects of a project on the Outstanding Universal Value (OUV) of a property (Francini, 2019).

To assess the possible impact on World Heritage, the first step is to identify the attributes that transmit Outstanding Universal Value. The attributes can be physical qualities, or processes that affect the environment of the site, such as natural, social or cultural processes. They are classified by reference areas. The following table shows the values and related attributes mentioned in the Statement of Outstanding Universal Values (SoOUV) (Figure 14). The attributes and values that are not explicitly mentioned in the documentation but that are considered important for the authenticity and cultural richness of the site are identified as potential. The importance of each value is classified on a rating scale from very high to negligible.

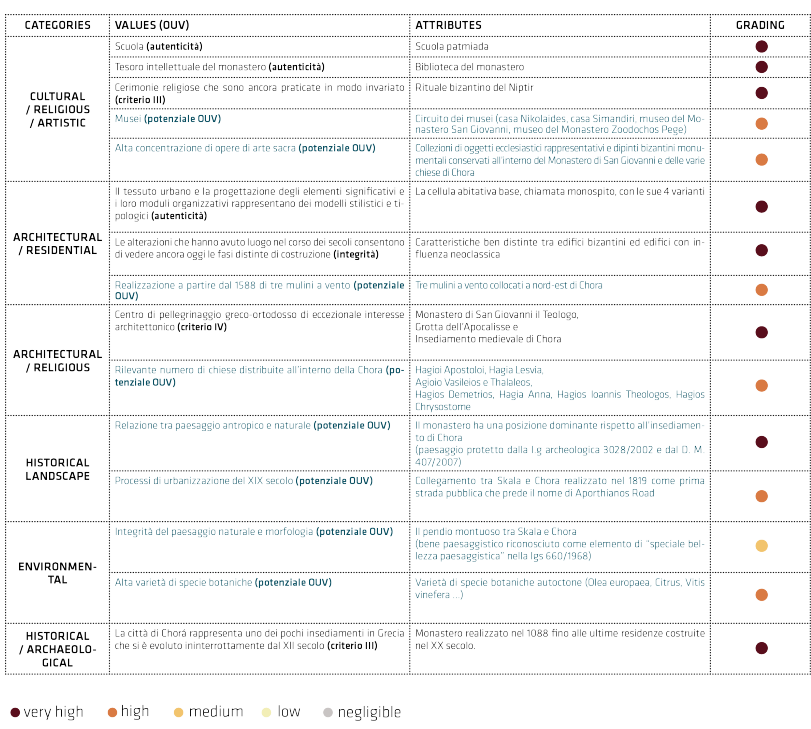

Figure 14. Exact from the table of the identification of attributes that convey OUV. Potential attributes are underlined in blue.
In the case of Patmos, HIA was applied to a rehabilitation intervention in the historic center (Figure 15). The assessment tool supported the design process, collaborating in defining intervention priorities to reduce the potential risks of the site, minimize negative impacts and maximize positive effects on the OUV (World Heritage Committee, 1999a; 1999b; 2014; 2016).



Figure 15. Masterplan whit the identified walk and the degraded areas; and zoom of two projects.

In identifying and assessing the values and attributes of the site, the importance of the role of the Monastery of Saint John the Theologian and the traditional architecture emerge. They narrate the transformations of the city over the centuries, from a social, technological and construction point of view. Particular attention must therefore be given to the protection of these aspects in the planning phase.

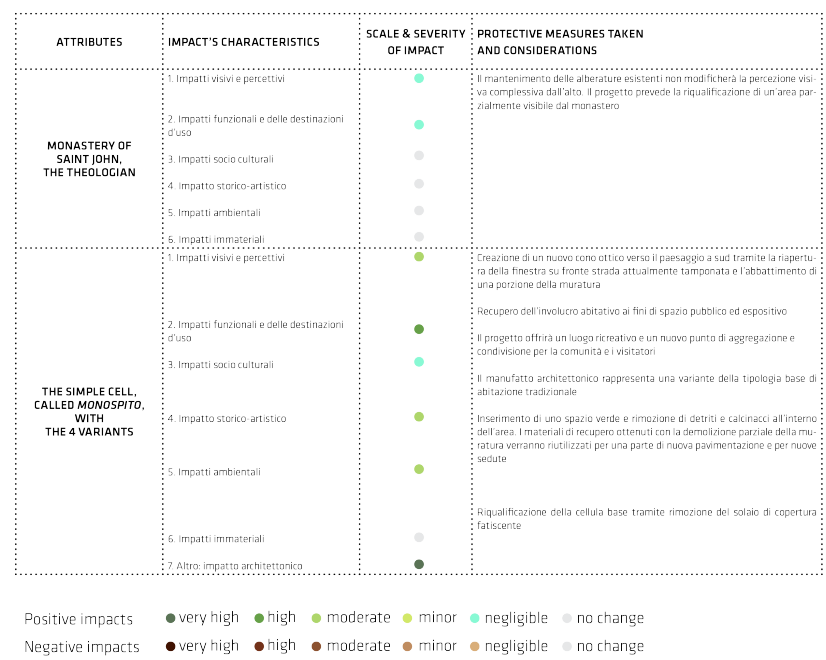

Figure 16. Extract from the scoping report carried out for one of the rehabilitation project for Chorá.

The preliminary self-assessment methodology takes into account the attributes conditioned by the project. For each attribute impacts have been assessed in relation to visual and perceptual aspects, functional and intended use; socio-cultural, historical and artistic, environmental and intangible aspects (Figure 16). 
The relevance of the impact on the assets is based on the scale specified in the ICOMOS 2011 Guidelines (appendix 3B Example guide for assessing the extent of the impact), which ranges from significant to absent, both in positive and negative terms.

In response to the Scoping Report, the evaluation committee draws up a report containing any recommendations and mitigating measures at the end of the HIA process. The strength of this evaluation lies in its being multidisciplinary and also recognizing social aspects as part of the identity culture of a Heritage.

\section{CONCLUSIONS}

The World Heritage sites characterized by the presence of vernacular architecture constitute a testimony of a material and immaterial culture made up of know-how that have shaped the built landscape over the centuries. Construction techniques and maintenance practices have been handed down over time, but they risk disappearing if they are not shared by the community and heritage experts.

The research conducted here was aimed at reconstructing the framework of vernacular knowledge conveyed by an architecture that thanks to its simple beauty and the values of authenticity and integrity has been named a World Heritage Site. The risk management techniques applied to the management of this heritage can help identify priorities in the definition of interventions aimed at recovering or safeguarding architecture. The application of HIA can provide an important contribution to manage changes and future transformations in order to preserve the cultural significance of the site and ensure its sustainable development.

\section{ACKNOWLEDGEMENTS}

This paper is the result of the research project 3D Past - "Living \& virtual visiting European World Heritage" [Grant Agreement Ref No570729-CREA-1-2016-1-PT-CULT-COOP1], which was co-funded by the European Union, under the programme Creative Europe (2016-2020).

\section{REFERENCES}

Arikan, F.D., 2015: Tracking continuities between the Modern and Vernacular Architecture: Courtyard in the West Mediterranean Architecture as a case study. In Master of Architecture, Middle East Technical University, not published.

Filindra, M., 1975: Development and changes in vernacular housing at Patmos Island. Architecture in Greece, 9, 166.

Francini, C. (eds.), 2019: Appunti per un modello di valutazione di impatto sul patrimonio (HIA). Firenze Patrimonio Mondiale, Florence.

Iakovides, Ch., Philippides, D., 1990: Greek traditional architecture. PATMOS. Melissa Publishing House, Athens.

ICOMOS, 2011: Guidance on heritage impact assessments for Cultural World Heritage Properties. ICOMOS, Paris. www.international.icomos.org/world_heritage/HIA_20110201. pdf.
Mecca, S., Masera, M., 2002: Il rischio nel progetto di costruzioni. ETS, Pisa.

Nijkamp, P., Riganti, P., 2008. Assessing cultural heritage benefits for urban sustainable development. International Journal of Services Technology and Management, 10(1), 29$3(2)$.

Pereira Roders, A., Van Oers, R., 2012. Guidance on heritage impact assessments: Learning from its application on World Heritage site management. Journal of Cultural Heritage Management and Sustainable Development, 2(2), 104-114. doi.org/10.1108/20441261211273671.

Philippides, D., 1999: Greek Traditional Architecture. Eastern Aegean, Sporades, Ionian Islands. Melissa Publishing House, Athens.

Theocharopoulou, I., 2009. Nature and the People: The Vernacular and the Search for a True Greek Architecture. Modern Architecture and the Mediterranean: Vernacular Dialogues and Contested Identities, edited by J.F. Lejeune, M. Sabatino, Routledge, Abingdon, 5, 111-130.

Olympitis, E., 1997: L'organizzazione della zona sull'isola di Patmos (XVII - XIX secolo). Master's thesis, University of Athens, not published.

Papadimitriou, B., 1982: Design of a prototype community in Greece. In Master of Architecture, University of Arizona, not published.

World Heritage Committee, 1999a. Nomination file 942. https://whc.unesco.org/en/list/942/documents.

World Heritage Committee, 1999b. Advisory Body Evaluation (ICOMOS). https://whc.unesco.org/en/list/942/documents.

World Heritage Committee, 2014. Periodic Report - Section II The Historic Centre (Chorá) with the Monastery of Saint-John the Theologian and the Cave of the Apocalypse on the Island of Pátmos. https://whc.unesco.org/en/list/942/documents.

World Heritage Committee, 2016. 40COM 8E - Adoption of Retrospective Statements of Outstanding Universal Value. https://whc.unesco.org/en/list/942/documents. 